\title{
Effect of Different Sugary Feeding on Pollen Gathering Activity of Honey Bee ( Apis mellifera L.) \\ Fathy, H. M. ${ }^{1}$; A. R.Hassan ${ }^{2}$; F. S. Srage Elden ${ }^{3}$ and D. F. M. Abd-Allaha ${ }^{1}$ \\ ${ }^{1}$ Economic Entomlogy Dept., Fac.of Agric.,Mansoura Univ \\ ${ }^{2}$ Plant Protection Dept.,fac.of Agric.,Minia Univ. \\ ${ }^{3}$ Plant Protection Research. Institute Agric. Dept.,ARC. Egypt.
}

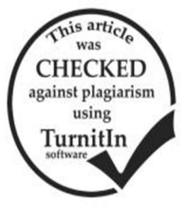

\begin{abstract}
The present investigation was carried out to study the effect of four types of sugary feeding (Glucose, Fructose ,Molasses and Moringa ) on pollen gathering activity of honey bee craniolan hybrid (Apis mell: fera. L.) by estimation of stared pollen amounts. The results indicted that, the average total number of square inches of stored pollen were $3116,3132,2825,3552$ and 2566 sq. in/ colony for those Treated with Glucose, Fructose ,Molusses Moringa and control, respectively. The highest rate of gathering pollen was observed during July and May 740 and $685 \mathrm{sq}$. in/ colony respectively. Moringa gave the highest number of stored pollen $3552 \mathrm{sq}$. in/colony a whole year than other syrups, while Treated colonies with Molasses gave the lowest number of stored pollen $285 \mathrm{sq}$. in/ colony. Also, the lowest amounts of stored pollen were observed during autumn and winter season in all treatment colonies.
\end{abstract}

\section{INTRODUCTION}

Feeding of bees is very important in bee breeding as it help much in maintain strong hives with sufficient brood during the whole season. Honey bee Apis mellifera L., colonies can be stimulated to increase in population, even in the absence of sufficient for age, by providing sugar syrup. However, colony growth and maintenance are limited by the protein available. Protein, normally in the form of pollen, is necessary for the production of bee brood (Brodschneider and Crailshein, 2010).

Colonies that have no access to protein and sugars during the active season have a reduced capacity to rear replacement bees, quickly decline in population, and may eventually die. The wintering ability survival rates of adult bees and brood areas were positively affected by feeding and feed additives ( Akyelet et. al., 2006) Honeybee.

1- Moringa olefera is a tropical tree possessing numerous economic applications. Plus growing internationalinterest, Moringa tree is cultivated and-used as a vegetable ( leaves, green pods, flowers, roasted seeds), for spice (mainly roots), for cooking and cosmetic oil ( seeds ) and as a medicinal plant ( all plant organs), ( Rebecca et al, 2006 ) .

2- Busani et al., (2011) found that the dried leaves had crude protein levels of $30.0 \%$ and 19 amino acids. The dried leaves had the following mineral contents : calcium $(3.65 \%)$, phosphorus $(0.3 \%)$, magnesium $(0.5 \%)$, potassium $(1.5 \%)$, sodium $(0.164 \%)$, silphur $(0.63 \%)$, zinc $(13.03 \% \quad \mathrm{mg} / \mathrm{kg}), \quad$ copper $(8.25 \%)$, manganese $(86.8 \mathrm{mg} / \mathrm{kg})$, iron $(490 \mathrm{mg} / \mathrm{kg})$, and selenium $(363 \mathrm{mg} / \mathrm{kg}$ ). The values of amino acids, minerals and vitamins profiles reflect desirable nutritional balance.

Apis mellifera L. depend mainly on nectar and pollen as sources of nutrients, where nectar provides the bees with carbohydrates while pollen supplies with the remaining ditary requirements such as proteins, lipids , vitamins and minerals . ( Brodschueider and Crailoheim 2010 and keller et al., 2005 a \&b).Sometimes , nectar and pollen grains are not available or they in short supply .

During the shortage or complete absence of pollen, or in the presence of only poor quality pollen, beekeepers often feed colonies of honeybees with pollen substitutes (with no pollen) or supplemented diets (with pollen), these are ideal materials that provide required nutrients to bees ( Saffari et al., 2004 ) .

The type and period of sugary feeding play an important role. Such feeding affects brood rearing and productivity of colonies., therefore , the present study was designed to evaluate effect of such feeding on pollen gathering activity ( amount of stored pollen ).

\section{MATERIALS AND METHODS}

The experiment was performed in a private apiary at Smalot district , Minia Governorate from September 2015 up to August 2016.

Fifteen colonies in the same strength ( 6 combs ) of craniolan hybrid (Apsi mellifera L.). In the standard longstroth hives, having metad queens of the same age were selected.

This study was demonstrated by choosing four sugary deits . These colonies were divided in one group according feeding periods (Autam and Winter). The experiment include 12 colonies divided into four group (each contain 3 colonies ) and three colonies used as control for all experiments as follows :

- Group A : Untracted colonies left as control for all experiments .

- Group B: Glucose candy .

- Group C : Fructose candy .

- Group D : Molasses candy .

- Group E : Moringa candy .

Preparation of sugary feeding :

Four types of sugary feeding were used Glucose , Fractose, Molasses , Moringa solution. All feeding types were used as candy as follows .

1- Glucose candy (500 g. glucose syrup + 1000 g. powder Sacarose).

2- Fructose candy (500 g. fructose syrup +1000 g. powder Sacarose).

3- Molasses candy (500g. sugar came syrup (Molasses) +1000 g. - powder sacarose).

4- Moringa candy [500 g. Moringa solution, (leaf extraction $)]+1000 \mathrm{~g}$. powder Sacrose.

Untreated colony (control) : (500 g. Sucrose syrup ( 1: 1) used for all expenital colonies during the dearth of nectar at seven days interval. 
Each colony was fed at intervals of 12 days, with $200 \mathrm{~g}$. of the sugary diet according to feeding periods .

The feeding was introduced to bees as a pasta (candy) in small plastic cup $(10 \mathrm{~cm}$ diameter $\mathrm{x} 6 \mathrm{~cm}$. deep.) according to ( Fathy, 1993 ). Stored pollen was measured according to time and feeding types on a whole year (2015-2016).

The quantities of food consumed by the colonies were determined at the end of 12 days intervals by weighing the feeding cups.

Estimation of Stored pollen :

In this study for estimating the mount of stored pollen for each treatment during a whole year, a typical longstroth frame was divided into square inches by means of wire .

This frame was laid against any comb In which it was desired to count the number of square inches of stored pollen. The counts were made at intervals of 12 days, this method of counting was according to AlTikrity etal., (1971) .

The areas of stored pollen was estimated throughout one whole years (2015 -2016) .

Estimation of stored pollen :

The same previous method of brood rearing counting was at 12 days intervals, to count the number of squares inches of stored pollen .

\section{RESULTS AND DISCUSSION}

The present study indicated that the lowest amounts of stored pollen were recorded in Autumn and results are not in agreement those results obtained by Fathy (1998) who mentioned that the lowest amounts of stored pollen in both strong and week colonies were recorded in winter.

Also, the results are in agreement with (Free and spencer (1969) mentioned that, most of the increase in pollen collection accurse during syrups feeding usually disappeared soon after feeding is discontinued .
Analysis of variance showed that there are significant differences between untreated and treated colonies with Molasses, and Moringa in Autumn, spring and summer. But no significant differences occurred between the treated colonies with Glucose, Fructose and Moringa in spring.

Pollen gathering activity :

The results in table 1 and Figs. 1,2 represented the average of a 12 days estimation of the amount of the stored pollen. The average total number of stored pollen (square inch per colony) over a whole year were $3116,3132,2875,3552$ and 2566 sq. in/colony for each treatment, Glucose , Fructose , Molasses, Moringa and control, respectively.

As shown in table 1 and Fig. 1, pollen gathering activity in treated and untreated colonies with different sugary feeding exhibited two peeks May and July. Gathering and storing pollen began slightly during December recording 10 sq. in $(0.57 \%)$ and 23 sq. in $(0.64 \%)$ in treated colonies with Molasses, Fructose, Glucose and Moringa, respectively. Count of stored pollen increased to 347 sq. in / colony in treated colonies with Moringa while it was 234 sq. in/ colony in treated colonies with Molasses .

The peak of pollen gathering was observed during May and July in treated colonies with Fructose 749 sq. in/ colony and 556 sq. in / colony , representing 23.91 and $17.75 \%$, respectively, while in treated colonies with Moringa was 685 and 740 sq. in/ colony, representing 19.28 and 20.83 , respectively. The average number of stored pollen declined during September to 24 sq. in / colony, representing $0.42 \%$ and 44 sq. in / colony $(1.23 \%)$ in treated colony with Fructose and Moringa, respectively . Fig. 3 In October, the average number of stored pollen contained to decline to 32 . Sq. in/ colony (1.02\%) in treated colonies with Fructose and 48 sq. in / colony $(1.35 \%)$ in treated colonies with Moringa.

Table 1. Monthly and Total count of stored pollen Treated colonies with different sugary feeding (Autumn and winter) during the whole year (2015-2016).

\begin{tabular}{|c|c|c|c|c|c|c|c|c|c|c|c|}
\hline \multirow{2}{*}{ Season } & \multirow{2}{*}{ Month } & \multicolumn{10}{|c|}{ Treatment } \\
\hline & & Control & $\%$ & Glucose & $\%$ & Fructose & $\%$ & Molasas & $\%$ & Moringa & $\%$ \\
\hline \multirow{4}{*}{ Autumn } & Sept. & 56 & 2.18 & 46 & 1.47 & 29 & 0.92 & 26 & 0.92 & 44 & 1.23 \\
\hline & Oct. & 50 & 1.94 & 54 & 1.73 & 32 & 1.02 & 20 & 0.70 & 48 & 1.35 \\
\hline & Nov. & 65 & 2.53 & 39 & 3.25 & 50 & 1.59 & 46 & 4.62 & 64 & 1.80 \\
\hline & Total & 171 & 6.66 & 139 & 4.46 & 111 & 3.5 & 87 & 3.08 & 156 & 4.39 \\
\hline \multirow{4}{*}{ Winter } & Dec. & 27 & 1.05 & 18 & 0.57 & 12 & 0.38 & 10 & 0.35 & 23 & 0.64 \\
\hline & Jan. & 113 & 4.40 & 56 & 1.79 & 50 & 1.59 & 38 & 1.34 & 32 & 0.90 \\
\hline & Feb. & 49 & 1.90 & 51 & 1.63 & 44 & 1.40 & 70 & 2.47 & 60 & 1.68 \\
\hline & Total & 189 & 7.36 & 1.25 & 4.01 & 106 & 3.38 & 118 & 4.18 & 115 & 3.23 \\
\hline \multirow{4}{*}{ Spring } & Mar. & 237 & 9.23 & 290 & 9.30 & 277 & 8.84 & 234 & 8.28 & 347 & 0.76 \\
\hline & Apr. & 218 & 8.49 & 293 & 9.40 & 363 & 11.59 & 304 & 10.76 & 343 & 9.65 \\
\hline & May & 218 & 8.49 & 654 & 2.98 & 749 & 23.91 & 710 & 25.13 & 685 & 19.28 \\
\hline & Total & 673 & 26.22 & 1237 & 39.69 & 1389 & 44.34 & 1248 & 44.17 & 1375 & 38.72 \\
\hline \multirow{4}{*}{ Summer } & Jun & 411 & 16.01 & 441 & 14.15 & 500 & 15.96 & 416 & 14.72 & 524 & 14.75 \\
\hline & Jul. & 639 & 24.90 & 684 & 21.95 & 556 & 17.75 & 538 & 19.04 & 740 & 20.83 \\
\hline & Aug. & 483 & 18.82 & 490 & 15.72 & 470 & 15.0 & 418 & 14.79 & 642 & 18.08 \\
\hline & Total & 1533 & 59.74 & 1615 & 51.82 & 1526 & 48.75 & 1372 & 48.75 & 1906 & 53.65 \\
\hline Total year & & 2566 & 100 & 3116 & 100 & 3132 & 100 & 2825 & 100 & 3552 & 100 \\
\hline
\end{tabular}




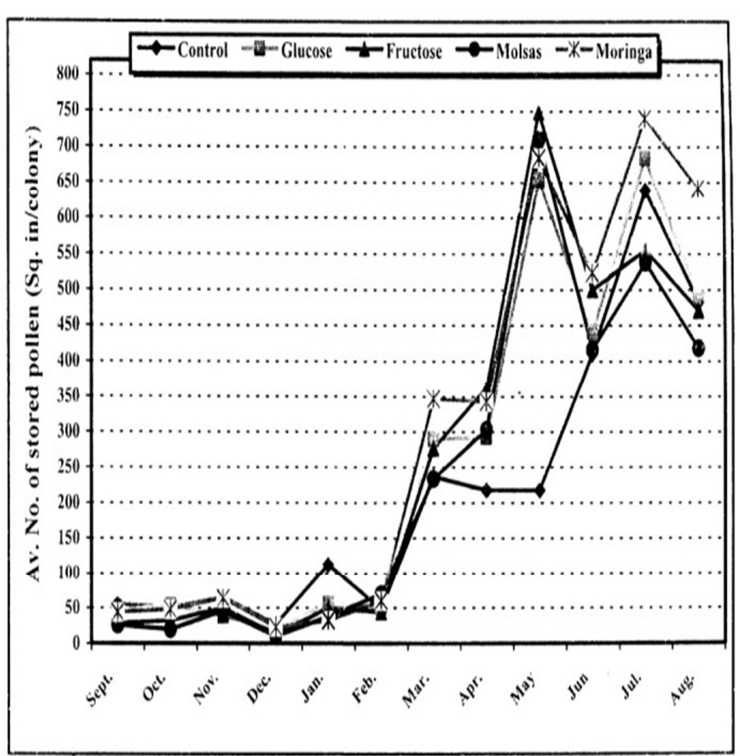

Fig. 1. Total count of stored pollen treated colonies with different sugary feeding (autumn and winter) during the whole year (2015-2016) .

The results illustrated in Fig. 1, 2 are similar to the pervious data, which proved that colonies treated with Moringa gave the highest number of stored pollen 3552 sq. in/ colony . Over a whole year. Than any other feeding, while treated colonies with Molasses, gave the lowest amounts of stored pollen reached to 2825 sq. in / colony.

Fig. 2,3 also gives comparative illustration of differences between the four sugary feeding and the control using the average number of stored pollen square inches during the experiment period. The highest amounts of stored pollen were observed during summer season gave $1906,1615,1526$ and 1372 sq. in /colony represented $53.65 \%, 51.82 \%, 48.75 \%$ and $48.75 \%$ in treated colonies Moringa, Glucose, Fructose and Molasses, respectively. Most of the pollen grains were collected in May (Fig. 1) the highest percentage of stored pollen was due to the soil ability of the ecological

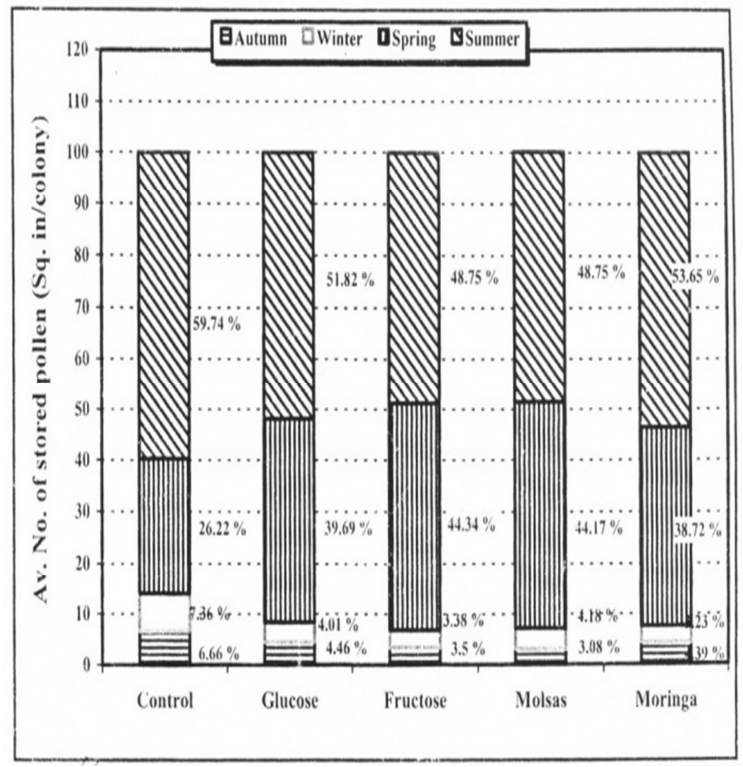

Fig. 2. Total amount and percentage (\%) of stored pollen under the influence of different sugar feeding during the four seasons of the year 2015-2016 ( autumn and winter) .

conditions for plant flowering and the highest population of foraging bees that could gather the pollen from the blooming plants in this period. The lowest amounts of stored pollen were during autumn and winter season is a results of the lack in pollen sources and digresses of temperature degree epically during December and January which affect the foraging activity of bees. Concerning the effect of feeding colonies with different sugary on amount of stored pollen, The obtained results indicated that treated colonies with Moringa were more active in called pollen during summer and spring season 1906 and 1375 sq. in / colony, respecting $53.65 \%$ and $19.28 \%$, respectinly .While treated colonies with Molasses collected during the same season, recorded. 1372 and 1248 sq. in / colony respectively and between four feeding types in winter ( table : 2 ).

Table 2. Statistical analysis of stored pollen treated colonies with different sugary feeding ( autumn and winter) during the whole year (2015-2016).

\begin{tabular}{lccccc}
\hline Treatments & Autumn & Winter & Spring & Summer & The whole year \\
\hline Glucose & $139.0 \mathrm{abc}$ & $125.0 \mathrm{~b}$ & $1237.0 \mathrm{~b}$ & $1615.0 \mathrm{~b}$ & $3116.0 \mathrm{~b}$ \\
Fructose & $111.0 \mathrm{bc}$ & $106.0 \mathrm{~b}$ & $1389.0 \mathrm{a}$ & $1526.0 \mathrm{~b}$ & $3132.0 \mathrm{~b}$ \\
Molsas & $92.0 \mathrm{c}$ & $118.0 \mathrm{~b}$ & $1248.0 \mathrm{~b}$ & $1372.0 \mathrm{~b}$ & $2830.0 \mathrm{bc}$ \\
Moringa & $156.0 \mathrm{ab}$ & $115.0 \mathrm{~b}$ & $1375.0 \mathrm{a}$ & $1906.0 \mathrm{a}$ & $3552.0 \mathrm{a}$ \\
Control & $171.0 \mathrm{a}$ & $189.0 \mathrm{a}$ & $673.0 \mathrm{c}$ & $1533.0 \mathrm{~b}$ & $2566.0 \mathrm{c}$ \\
LSD at 0.05 & 15.9 & 12.0 & 20.5 & 83.6 & 31.5 \\
\hline
\end{tabular}

The means in the same column followed by the same litters do not differ significantly at level 0.05 .

\section{REFERENCES}

Al-Tikrity, W.S; R.C. Hippmann; A.W. Benton and w.w. Clarke . (1971) A new instrument for brood measurement in a honey becoloby . Amer, Bee J., $111(4): 143-145$.
Akyel, E; H. Yeninar; N. Sahinler and a.Guler (2006) The effect of additive feeding and feed additive before wintering on honey bee colony performances, wintering and survival rates at the East Mediterranean Region. Pakist. J. boil. Sci., 9 (4) $; 589-592$. 
Brodschneider, R. and K. Crailshem (2010) Nutrition and health in honey bees. Apidologie, 41(3):278 $-294$.

Busani, M., J.M.Patric, H. Amold and M.Voster.(2011). Nutritional characterization of Moringa(Moringa oleferalam.) leaves. African Journal of biotechnology, 10(60:1295-12933.)

Keller, I.; P. Fluri and A. Imdorf (2005). Pollen nutrition and colony development in honey beespart II. Bee world J., 33(4):125-128.

Rebecca, h. S. U. ; M. Sharon, A. Arbaunsyah and D. Lucierne. (2006).moringa oleifera: medicinal and socio - economic uses : International Course on Economic Botany. National Herbartium Leiden uses: International Course on Economic Botany. .National Herbarium Leiden Netherlands S. PP. 2- 6.

Brodschneider, R.; Riessberger-Galle, U.and K. Crailsheim (2009). Flight performance of artificially reared honeybees (Apis mellifera). Apidologie; 40(4):441449.
Shower, M. B; Z. Shenishen and N.M. El-Dakhakhni (1986). Major pollen sources in Kafer El : Sheikh , Egypt , and therole of pollen on brood area and honey yield J. Agaric Res, Tanta Univ.

Fathy, H.M. (1998). Seasonal variations in brood activity and stored pollen according to colony 6237 Strength. J. Agric. Sci. Mansoura Univ. 23 (12) : 6231 .

Fathy, H.M. (1993). Effect of certain diets on brood rearing of the honey bee abis mellifera L. J. Agriculture . Sci. Mansoura Univ. 18 (9) : 2728 2733.

Free , J.B. and R.S. Spencer (1967). Factors determining the collection of pollen by honey bee foragers Anim Behar. 15(1) : 134- 144 .

Saffari, A. M., Kevan, P. G. and Atkinson, J. L. (2004). A promising pollen substitute for honey bees. American Bee Journal 144:230-231.

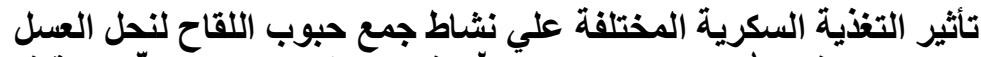

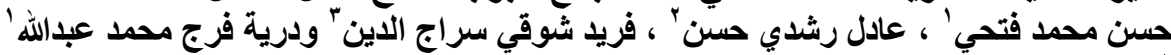

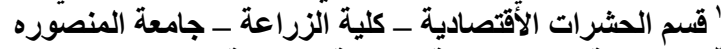

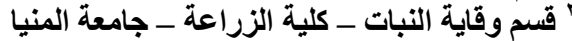

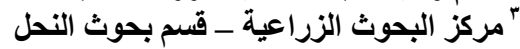

أجري هذا البحث لدر اسة تأثير أربعة أنواع من التغذية السكرية (الجلوكوز و الفركتوز والعسل الأسود والمورنجا) علي نشاط

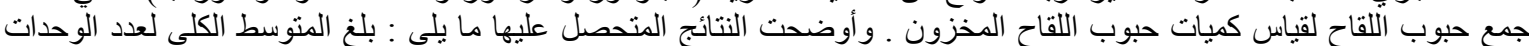

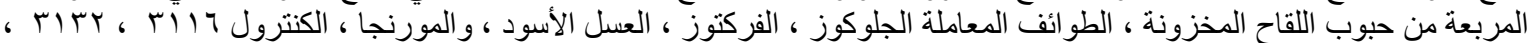

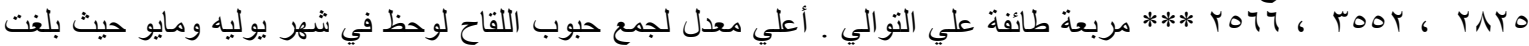

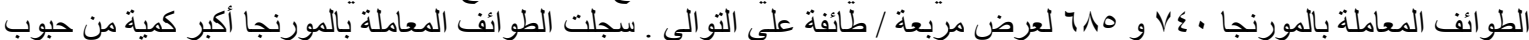

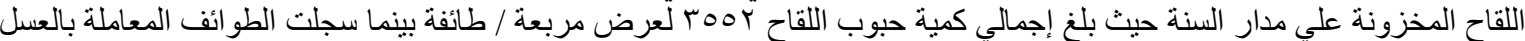

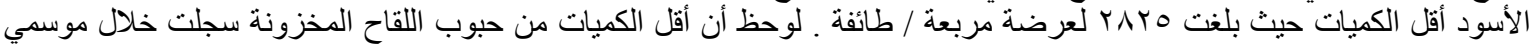

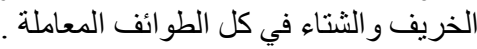

